\title{
SKRINING BAKTERI BERPOTENSI PENDEGRADASI POLIETILEN OXO-DEGRADABLE DARI TANAH GAMBUT DI SEKITAR TPA KUALA DUA RASAU JAYA
}

\author{
Nadhifah Rizqi Firdaus ${ }^{1}$, Rahmawati ${ }^{1}$, Riyandi ${ }^{1}$ \\ ${ }^{1}$ Program Studi Biologi, Fakultas MIPA, Universitas Tanjungpura, J1. Prof. Dr. H. Hadari Nawawi, Pontianak \\ Email korespondensi: nadhifarfir@gmail.com
}

\begin{abstract}
The use of polyoethylene degradable polyethylene in Indonesia, especially in West Kalimantan, is high enough to potentially cause environmental pollution. One way to resolve pollution caused by polyethylene oxo-degradable plastic waste is to utilize isolates from the peat soil around the Kuala Dua Final Disposal Site, Rasau Jaya, which is able to degrade oxo-degradable polyethylene. This research aims to determine the bacterial genera that can to be expected to degrade Oxo-Degradable Polyethylene. Samples were taken from peat soil with the incubation method of oxo-degradable polyethylene for 2 weeks, 4 weeks and 6 weeks. Isolation use the pour plate method with Enrichment Broth Media and Enrichment Agar Media. The isolation results obtained 9 (nine) bacterial isolates which are distinguished based on incubation time and morphological characters.
\end{abstract}

Key Word : Oxo-degradable polyethylene, Bacteria, Peat soil, Incubation

\section{PENDAHULUAN}

Plastik merupakan komoditi paling banyak digunakan sebagai keperluan sehari-hari, misalnya sebagai kemasan bahan makanan dan minuman. Produksi plastik di seluruh negara lebih dari 100 juta ton/tahun dan $40 \%$ dari sampah plastik dikelola dengan cara ditimbun dalam tanah (Zusfahair, 2007). Penimbunan sampah plastik akan membutuhkan waktu yang sangat lama dalam proses degradasi dan akan terakumulasi di Tempat Pembuangan Akhir (TPA).

Jenis plastik yang dapat didegradasi secara biologi (biodegradable plastic) merupakan solusi yang dapat digunakan untuk mengatasi masalah penimbunan sampah plastik di alam. Salah satu jenis biodegradable plastic adalah plastik oxo-biodegradable.Plastik jenis ini mengandung bahan tambahan berupa ion-ion logam yang berfungsi dalam proses oksidasi secara fisika oleh cahaya dan suhu. Hasil oksidasi plastik tersebut menghasilkan senyawa-senyawa dengan berat molekul rendah seperti asam karboksilat, alkohol dan keton yang dapat digunakan oleh mikroorganisme termasuk bakteri sebagai sumber karbon (Suresh et al., 2011; da Luz et al., 2013).

Bakteri pendegradasi plastik dapat ditemukan di alam baik di air maupun di tanah. Baberapa genus bakteri pendegradasi plastik berhasil diisolasi dari air laut diantaranya anggota genus Shewmanella sp., Moritella sp., Psycrobacter sp., Pseudomonas sp., dan Vibrio sp. (Urbanek et al., 2018). Berdasarkan informasi hasil penelitian, beberapa genus bakteri yang diisolasi dari sumber tanah yang berbeda terbukti mampu mendegradasi plastik polietilen oxo-degradable. Hasil penelitian menunjukkan bahwa bakteri yang diisolasi dari tanah sampah dan tanah mangrove di India yaitu anggota genus Pseudomonas, Bacillus, Xanthomonas, Flavobacterium, Agrobacterium, Streptomyces, Micrococus, dan Moraxella mampu mendegradasi polietilen oxo-degradable (Gupta et al., 2010; Usha et al., 2011; Kathiresan, 2003). 


\section{BAHAN DAN METODE}

\section{Waktu dan Tempat Penelitian}

Penelitian dilaksanakan mulai dari bulan Juni hingga bulan Desember 2018. Pengambilan sampel dilakukan di Tempat Pembuangan Akhir (TPA) Desa Kuala Dua, Rasau Jaya, Kabupaten Kubu Raya. Isolasi, karakterisasi, identifikasi serta analisis data dilakukan di Laboratorium Mikrobiologi, Fakultas Matematika dan Ilmu Pengetahuan Alam, Universitas Tanjungpura ,Pontianak. Analisis kandungan tanah gambut dilakukan di Laboratorium Fisika dan Konservasi Tanah, di Laboratorium Kimia,Fakultas Pertanian, Universitas Tanjungpura,Pontianak.

\section{Bahan}

Bahan yang digunakan adalah tanah gambut yang diambil dari lokasi penelitian, agar, akuades, amonium sulfat $\left[\left(\mathrm{NH}_{4}\right)_{2} \mathrm{SO}_{4}\right]$, bubuk Polietilen Oxo-degradable, Dipotasium Hidrogen Pospat $\left(\mathrm{K}_{2} \mathrm{HPO}_{4}\right)$, Natrium nitrat $\left(\mathrm{NaNO}_{3}\right)$, Kalium klorida $(\mathrm{KCl})$, Magnesium sulfat $\left(\mathrm{MgSO}_{4}\right)$, Tween 80 , Yeast extract, pewarnaan Gram yang terdiri dari larutan Kristal violet, larutan iodin, alkohol $96 \%$ dan larutan safranin 1\%, Media SCA (Simmon's Citrate Agar), Media TSIA (Triple Sugar Iron Agar), Media Basal OF (Oksidatif Fermentatif), larutan hydrogen peroksida $\left(\mathrm{H}_{2} \mathrm{O}_{2}\right) 3 \%$, media MIO (Motility Indole Ornithin) dan Urea agar base.

\section{Prosedur Kerja}

Pengambilan Sampel

Pengambilan sampel dilakukan pada tanah yang menempel pada polietilen oxodegradable yang telah diinkubasi selama 2 minggu 4 minggu dan 6 minggu pada tanah gambut di sekitar TPA Kuala Dua Rasau Jaya.

\section{Pembuatan Media}

Enrichment Broth Media

Bubuk Polietilen Oxo-degradable ditambahkan pada media sebagai sumber karbon bagi bakteri. Media cair diperkaya berisi 1 gram Amonium sulfat [ $\left.\left(\mathrm{NH}_{4}\right)_{2} \mathrm{SO}_{4}\right], 1$ gram Natrium nitrat $\left[\left(\mathrm{NaNO}_{3}\right)\right], 1$ gram Kalium klorida $[(\mathrm{KCl})], \quad 1$ gram Kalium hidro pospat
$\left(\mathrm{K}_{2} \mathrm{HPO}_{4}\right)$ ， 0,2 gram Magnesium sulfat $\left[\left(\mathrm{MgSO}_{4}\right)\right], \quad 0,1$ gram Yeast extract, dan kemudian dilarutkan di dalam 1Liter akuades steril ditambahkan potongan film strip polietilen oxo-degradable (Mukamto et al.,2015)

Enrichment Agar Media

Media agar diperkaya berisi 1 gram Amonium sulfat $\left[\left(\mathrm{NH}_{4}\right)_{2} \mathrm{SO}_{4}\right], 1$ gram Natrium nitrat [(NaNO 3$)], 1$ gram Kalium klorida $[(\mathrm{KCl})], 1$ gram Kalium hidro pospat $\left(\mathrm{K}_{2} \mathrm{HPO}_{4}\right), 0,2$ gram Magnesium sulfat $\left[\left(\mathrm{MgSO}_{4}\right)\right], 0,1$ gram Yeast extract dilarutkan ke dalam $12 \mathrm{~g} / \mathrm{L}$ agar ditambahkan $1 \mathrm{ml}$ Tween 80 dan film strip polietilen oxo-degradable setelah media agar di sterilisasi (Mukamto et al.,2015)

\section{Isolasi dan Skrining Bakteri Pendegradasi Oxo-degradable \\ Teknik Kultur}

Teknik Kultur merupakan teknik menumbuhkan bakteri dalam media pengayaan cair (Enrichment broth media). Teknik kultur dilakukan dengan cara melarutkan 1 gram sampel tanah ke dalam erlenmeyer sebanyak $20 \mathrm{~mL}$ media cair diperkaya lalu digojog dengan suhu $32^{\circ} \mathrm{C}$ selama 2 minggu menggunakan inkubator shaker dengan kecepatan $200 \mathrm{rpm}$ untuk memperoleh suspensi bakteri (Mukamto et al.,2015).

Pour Plate

Metode pour plate merupakan teknik isolasi bakteri dalam media pengayaan padat (agar) (Enrichment agar media) dengan cara suspensi bakteri yang telah didapatkan pada teknik kultur diambil $1 \mathrm{ml}$, kemudian dimasukkan ke dalam tabung reaksi $10^{-1}$ yang berisi $9 \mathrm{ml}$ Enrichment broth media yang baru. Kemudian dilakukan pengenceran (teknik dilusi), diambil $1 \mathrm{ml}$ dari tabung reaksi $10^{-1}$ hingga $10^{-}$ ${ }^{4}$.Sebanyak $1 \mathrm{ml}$ dari masing-masing pengenceran $\left(10^{-1}\right.$ dan $\left.10^{-4}\right)$ diambil dan dicampurkan ke dalam enrichment agar media dengan metode pour plate. Selanjutnya diinkubasi selama 2-7 hari pada suhu $32^{\circ} \mathrm{C}$ dan dilihat biofilm yang terbentuk (Mukamto et al., 2015).

\section{Pemurnian Isolat}

Pemurnian bakteri dilakukan dengan inokulasi koloni bakteri yang berasal dari hasil pengkulturan bakteri dengan metode goresan 
(streak methode). Pemilihan koloni dilakukan berdasarkan terbentuknya biofilm. Koloni bakteri yang akan dimurnikan ditentukan dari perwakilan tiap kelompok yang memiliki ciri yang sama. Media yang digunakan adalah enrichment agar media dengan penambahan film strip polietilen oxo-degradable dan diinkubasi selama 2-7 hari (Waluyo, 2008 dan Mukamto et al., 2015).

\section{Karakterisasi Isolat Bakteri}

Karakter bakteri yang diamati meliputi morfologi koloni dan morfologi sel bakteri. Karakter morfologi koloni bakteri yang diamati meliputi, bentuk koloni bakteri, elevasi, tepian koloni, dan warna koloni.

\section{Analisis dan Penyajian Data}

Data yang diperoleh dianalisis berdasarkan karakteristik pada setiap genus bakteri yang ditemukan. Data disajikan dalam bentuk Tabel, foto hasil pengamatan dan deskripsi.

\section{HASIL DAN PEMBAHASAN}

\section{Hasil}

Berdasarkan hasil penelitian diperoleh. Hasil isolasi yang dilakukan dari tanah gambut diperoleh bakteri yang membentuk biofilm dari pengenceran $10^{-4}$ dan $10^{-5}$ pada waktu inkubasi 2 (dua) minggu, 4 (empat) minggu dan 6 (enam) minggu (Gambar 1). Isolat ini dibedakan berdasaran karakteristik morfologis koloni bakteri yang tumbuh pada Enrichment Agar Media. Sel bakteri yang diduga sebagai pendegradasi polietilen oxo-degradable yang diisolasi dari tanah gambut (Gambar 2).

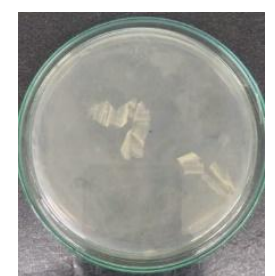

$\mathrm{a}$

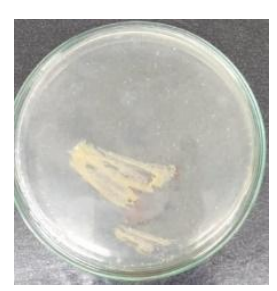

b

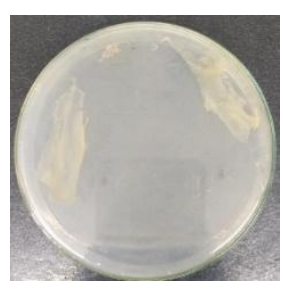

c

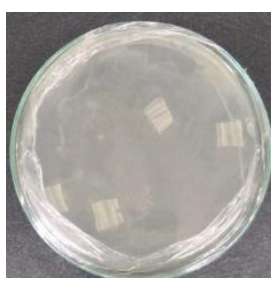

e

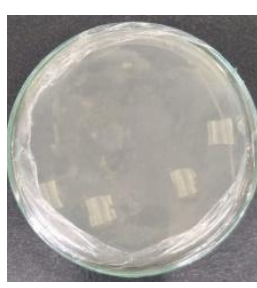

f

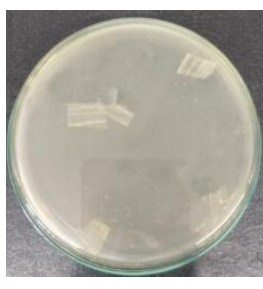

$\mathrm{g}$
Gambar 1. Lapisan Biofilm yang menutupi permukaan media dan potongan strip film polietilen oxodegradable

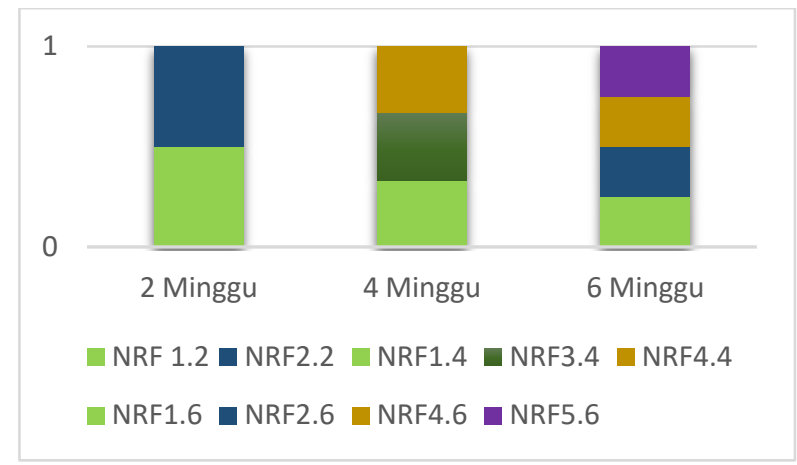

Gambar 2. Grafik Isolat Hasil Isolasi Berdasarkan Kesamaan Bentuk Koloni

(Waran sama menunjukkan koloni yang memiliki karakteristik morfologis yang sama )

Tabel 1. Parameter Faktor Lingkungan

\begin{tabular}{|c|c|c|c|c|c|}
\hline $\begin{array}{l}\text { Sampel } \\
\text { (Waktu }\end{array}$ & $\begin{array}{c}\text { Suhu } \\
\text { Tanah }\end{array}$ & $\begin{array}{c}\mathrm{pH} \\
\text { tanah }\end{array}$ & $\begin{array}{c}\text { C- } \\
\text { organik }\end{array}$ & $\mathrm{Mg}$ & K \\
\hline Inkubasi) & $\left(\mathrm{C}^{\circ}\right)$ & 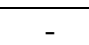 & $\%$ & \multicolumn{2}{|c|}{$(\mathrm{cmol}(+) \mathrm{kg}-1)$} \\
\hline 2 Minggu & $24-25$ & 3,3 & 56,64 & 3,86 & 0,72 \\
\hline 4 Minggu & $25-26$ & 3,40 & 56,60 & 4,06 & 0,71 \\
\hline 6 Minggu & $24-25$ & 3,42 & 56,61 & 3,92 & 0,70 \\
\hline
\end{tabular}

Faktor lingkungan dan kandungan kimiawi tanah yang diukur meliputi suhu tanah, $\mathrm{pH}$ tanah, kandungan $\mathrm{C}$-organik, kandungan $\mathrm{Mg}$ dan K. Hasil pengukuran faktor lingkungan dan kandungan kimia tanah pada tanah gambut di sekitar TPA Kuala Dua Rasau Jaya yaitu suhu tanah berkisar $24-26^{\circ} \mathrm{C}$, pH tanah 3,33,42, kandungan C-organik 56,64\%-56,61\%, kandungan Mg 3,86-4,06, kandungan K 0,70 0,72 (Tabel 1). 


\section{Pembahasan}

Berdasarkan hasil penelitian bakteri yang berhasil diisolasi dari sampel polietilen oxodegradable yang diinkubasi pada tanah gambut di sekitar TPA Kuala Dua Rasau Jaya pada waktu inkubasi dua, empat dan enam minggu membentuk lapisan biofilm pada Enrichment Agar Media. Biofilm terbentuk diduga merupakan hasi dari proses degradasi yang dilakukan oleh bakteri dengan cara mengeluarkan enzim ekstraselular. Hal ini dinyatakan oleh Thakur (2012), bakteri menggunakan potongan film polietilen sebagai satu-satunya sumber karbon. Polietilen oxodegradable yang telah diinkubasi di tanah gambut selama 2 (dua) hingga 6 (enam) minggu tersebut merupakan suatu senyawa asam lemak dengan rantai hidro karbon yang panjang yang dapat digunakan sebagai sumber C-organik bagi bakteri pendegradasi poloetilen oxo-degradable.

Berdasarkan hasil pengukuran kadungan Corganik pada tanah gambut sebesar 56,64\% (Tabel 2) kandungan C-organik yang cukup tinggi pada tanah gambut di sekitar TPA Rasau Jaya Kalimantan Barat dapat digunakan sebagai sumber energi bagi bakteri. Bakteri dapat memanfaatkan sumber karbon baik dari tanah gambut maupun dari polietilen oxodegradable. Keberadaan 9 (sembilan) isolat tersebut di tanah gambut juga didukung dengan kondisi lingkungan untuk pertumbuhan bakteri diantaranya suhu dan $\mathrm{pH}$ yang rendah (asam). Menurut $\mathrm{Gu}$ (2003), kondisi lingkungan seperti kelembapan, suhu, $\mathrm{pH}$, keberadaan oksigen, cahaya matahari, air dan salinitas tidak hanya mempengaruhi kecepatan degradasi polimer tetapi juga mempengaruhi populasi mikroba pendegradasi dan aktivitas enzim pendegradasi.

Isolat bakteri yang diisolasi dari tanah gambut pada penelitian ini, dapat digolongkan sebagai bakteri pendegradasi polietilen oxodegradable. Hal ini dapat dibuktikan dengan digunakannya media pertumbuhan yang hanya berisi garam-garam mineral dan polietilen oxodegradable sebagai satu-satunya sumber Corganik. Menurut Prabhat et al., (2013), bakteri pendegradasi polietilen oxo-degradable yang ditumbuhkan pada media yang hanya berisi garam-garam mineral tanpa sumber karbon akan berada dalam kondisi tercekam. Apabila diberikan sumber karbon berupa polietilen, maka bakteri akan menempel pada polietilen dan memanfaatkan karbon dari polietilen sebagai sumber energi untuk pertumbuhan. Sharma et al (2015) menyatakan bahwa, garam-garam mineral yang terkandung dalam media pertumbuhan bakteri pendegradasi polietilen berfungsi sebagai akseptor elektron dalam keadaan anaerob.

Berdasarkan hasil penelitian dapat dilihat bahwa terdapat penambahan jenis bakteri baru yang diperoleh dari waktu inkubasi polietilen oxo-degradable dua minggu, empat minggu dan enam minggu (Gambar 1) Hal tersebut diduga karena adanya komunikasi antara sel bakteri yang disebut dengan Quorum-sensing, dalam hal ini adalah sel bakteri pendegradasi polietilen. Menurut Waters dan Bassler (2015), sel bakteri akan membangun interaksi yang sesuai dengan sel bakteri lain dengan melibatkan sinyal berupa molekul-molekul kimia yang berfungsi sebagai otopengimbas (autoinducer). Proses ini memungkinkan satu sel bakteri dapat memantau lingkungan untuk bakteri lain sehingga akan mengubah jumlah sel bakteri dalam skala populasi maupun komunitas.

\section{DAFTAR PUSTAKA}

Gu, JD, 2003, Microbiological deterioration and degradation of synthetic polymeric materials: recent research advances. International Biodeterioration and Biodegradation vol 52, hal 69-91.

Gupta, SB, Ghosh, A \& Chowdhury, T, 2010, Isolation and selection of stress tolerant plastic loving bacterial isolates from old plastic wastes, World J Agric Sci. vol 6, no 2, hal 138-140.

Kathiresan K. 2003, Polythene and plasticsdegrading microbes from the mangrove soil. Rev Biol Trop, vol 51 no 3, hal 629-634.

Mukamto, Rahayu YS, Lisdiana \&L,Pranamuda H.,2015, Isolation Of Oxo-Degradable Polyethylene Degrading-Bacteria of Benowo Landfill Soil Surabaya. Microbiologi Indonesia, vol 9, no, hal 9-16 
Prabhat S, Bhattacharyya S, Vishal V, Kalyan R K, Vijai K, Pandey KN \& Singh M. 2013, Studies on isolation and identification of active microorganisms during degradation of polyethylene/ starch film. Int Res Journal Environment Sci. vol 2, no 9, hal.: 83-85

Singh G, Singh AK, Bhatt K, 2016, Biodegradation of Polythenes by Bacteria Isolated from Soil. J International Journal of Research and Development in Pharmacy and Life Sciences. vol.5 no. 2

Suresh B, Maruthamuthu S, Khare A, Palanisamy N, Muralidharan VS, \& Ragunathan R. 2011, Influence of thermal oxidation on surface and thermo-mechanical properties of polyethylene. J Polymers. vol 18, hal 217584

Sharma, M, Sharma, P, Sharma,\& Chandra, S, 2015, Microbial Degradation of Plastic - A Brief Review , CIBTech Journal of Microbiology, vol.4, hal 85-89

Thakur, P, 2012, Screening of Plastic Degrading Bacteria from Dump Soil Area, Thesis, ODHISA Departement of Life Science, National Institute of Technology

Tokiwa, Y, Calabia BP, Ugwu CU \& Aiba S. 2009, Biodegradability of plastics. Int Journal Mol Sci. vol 10, no 9 hal 3722-3742

Urbanek, AK, Rymowicz,W, Mironczuk, AM, 2018, Degradation of Plastic and Plasticdegrading Bacteria in Cold Marine Habitats,Applied Microbiology and Biotechnology Journal, vol 102(18), hal 7669-7678

Usha R, Sangeetha T \& Palaniswamy M. 2011, Screening of polyethylene degrading microorganisme from garbage soil. Libyan Agriculture Research Center Journal Internasional. vol 2, no 4, hal.: 200-204

Waters CM \& Bassler BL, 2005, Quorum Sensing: Cell-to Cell Communication in Bacteria, The Annual Review of Cell and Developmental Biology. Department of Molecular Biology, Princeton University, Princeton, New

Waluyo, L, 2008, Teknik Dan Metode Dasar Dalam Mikrobiologi, Universitas Muhammadiyah Malam Press, Malang

Zusfahair, Lestari, P, Ningsing, DR, \& Widyaningsih, S, 2007, Biodegradasi polietilen Menggunakan Bakteri dari TPA (Tempat Pembuangan Akhir) Gunung Tugel Kabupaten Banyumas, Jurnal Molekul, vol. 2 no.2, hal.: 98-106 
Protobiont

Volume:

Tahun: 2019 